\title{
Information Technology in University Education
}

\author{
Hung Hoang Bao \\ Korea - Vietnam Friendship Information Technology College, MIC, Vietnam \\ hunghb@viethanit.edu.vn
}

\begin{abstract}
One of the effective tool to enhance the ability to manage and supervise the training process, operating system in at university is the application of information and communications technology, on both the technical aspects and interactive environment. The investment in a strategic way from for technical infrastructure, equipment, manpower highly qualified highly qualified manpower and information infrastructure is the decisive factor to create the foundation for sustainable development in each stage of development of the Viet Nam universities in Vietnam.
\end{abstract}

Keywords: IT applications in Education, Information System, Technical Infrastructure Technology Infrastructure, Database System, e-GOV

\section{Introduction}

With a recent mass appearance of domestic universities and colleges throughout Vietnam ranging from public to private ones, from specialized to vocational training ones, the human resource training becomes diversified in the eyes of employers. The corollary of inadequate development between professional school systems and the national and local socioeconomic development has been anticipated by the imbalance of supply and demand in human resource market, creating a "saturation" in a certain of industries and a "forced" diversity of branches. Names and curricula of branches bear no relation to the ability to make use of social human resources, forming a somber picture of a vicious circle: Study - Job - Study. Nevertheless, this reality makes a breakthrough of a group of universities and colleges which either owns a depth of history or a methodical and strategic investment in human resource. They build up their reputation through their products - a qualified human resource accepted and effectively used by the society. This proves a professional investment in educational institutions including long term and medium term investment projects and scientific strategies of human resource development that waits in front for the development trends of science and technology that go along with the regional and national socio-economic development though stages.

The stability of this university system does not lie in the continuing increase in training majors but in the development of training quality in conformity with the rapid development of science and technology. Among factors that constitute such achievements is the professional management of universities and colleges, like a machine that runs in a highly interactive line, requiring a management ability correspondent to the development in quantity, training methods and areas. One of the useful tools that support the training process management and supervision and university operation is the application of IT and communication in both technique and interactive environment. 


\section{Information Technology in University Education: Solutions}

The IT applications in management and administration has been formed and developed through various generations with a variety of models and methods, among which ERP is the solution that works on the ground of IT applications in management. It enables organizations/ enterprises to perfect their management to effectively make use of resources in production in order to cope with the increasing competitition pressure and the pressure of supplying better and cheaper products, better and faster services.

In the education, ERP has been adjusted, added or removed a certain mumber of modules such as personnel management (officers and students), financial management, library management, degree management, learning and training management, facilities management, etc.

\begin{tabular}{|c|c|c|c|c|c|c|c|c|c|c|c|c|c|}
\hline \multirow{2}{*}{$\begin{array}{c}\begin{array}{c}\text { Organization } \\
\text { management }\end{array} \\
\begin{array}{c}\text { Customer } \\
\text { management }\end{array}\end{array}$} & \multicolumn{2}{|c|}{$\begin{array}{l}\text { Decision } \\
\text { support and } \\
\text { datastore }\end{array}$} & \multicolumn{2}{|c|}{$\begin{array}{l}\text { Expenditure } \\
\text { calculation }\end{array}$} & \multicolumn{2}{|c|}{ Disbursement } & \multicolumn{3}{|c|}{ Finance } & \multicolumn{3}{|c|}{ Accounting } & \multirow{2}{*}{$\begin{array}{c}\begin{array}{c}\text { Income } \\
\text { management }\end{array} \\
\begin{array}{c}\text { School } \\
\text { publicizing }\end{array}\end{array}$} \\
\hline & $\begin{array}{l}\text { Market } \\
\text { research } \\
\text { and } \\
\text { analysis }\end{array}$ & \multicolumn{2}{|c|}{$\begin{array}{l}\text { Product } \\
\text { dvertising }\end{array}$} & \multicolumn{2}{|c|}{$\begin{array}{c}\text { Programme } \\
\text { management }\end{array}$} & \multicolumn{2}{|c|}{$\begin{array}{c}\text { Sales } \\
\text { management }\end{array}$} & $\operatorname{Rec}$ & ruitme & \multicolumn{3}{|c|}{$\begin{array}{l}\text { Former student } \\
\text { afafirs }\end{array}$} & \\
\hline $\begin{array}{l}\text { Teaching and } \\
\text { learning }\end{array}$ & $\begin{array}{c}\text { Curriculu } \\
m \\
\text { planning }\end{array}$ & \multicolumn{2}{|c|}{$\begin{array}{l}\text { Learning and } \\
\text { testing } \\
\text { planning }\end{array}$} & \multicolumn{2}{|c|}{$\begin{array}{c}\text { Student } \\
\text { management }\end{array}$} & \multicolumn{2}{|c|}{$\begin{array}{c}\text { Student account } \\
\text { management }\end{array}$} & \multicolumn{2}{|c|}{$\begin{array}{l}\text { Teaching and } \\
\text { testing } \\
\text { management }\end{array}$} & \multicolumn{3}{|c|}{$\begin{array}{c}\text { Classroom } \\
\text { management and } \\
\text { E-learning }\end{array}$} & $\begin{array}{l}\text { Student } \\
\text { information } \\
\text { public } \\
\text { services }\end{array}$ \\
\hline $\begin{array}{l}\text { Scholarship } \\
\text { management }\end{array}$ & \multicolumn{2}{|c|}{$\begin{array}{l}\text { Scholarship } \\
\text { planning }\end{array}$} & \multicolumn{2}{|c|}{$\begin{array}{c}\text { Scientific } \\
\text { research } \\
\text { management }\end{array}$} & \multicolumn{2}{|c|}{$\begin{array}{l}\text { Accounting for } \\
\text { Sponsored } \\
\text { programmes }\end{array}$} & & \multicolumn{4}{|c|}{$\begin{array}{l}\text { Reimbursement for } \\
\text { sponsored programmes }\end{array}$} & \multicolumn{2}{|c|}{$\begin{array}{l}\text { Sponsor report and } \\
\text { agreement liquidation }\end{array}$} \\
\hline $\begin{array}{l}\text { Learning and } \\
\text { student } \\
\text { services }\end{array}$ & $\begin{array}{c}\text { Learning } \\
\text { informatio } \\
\text { portal }\end{array}$ & \multicolumn{2}{|c|}{$\begin{array}{l}\text { Study and job } \\
\text { consultancy }\end{array}$} & \multicolumn{2}{|c|}{$\begin{array}{l}\text { Expenditure } \\
\text { support }\end{array}$} & & $\begin{array}{l}\text { ccommod } \\
\text { on service }\end{array}$ & & \multicolumn{2}{|c|}{$\begin{array}{l}\text { Room and } \\
\text { equipment } \\
\text { services }\end{array}$} & \multicolumn{2}{|c|}{$\begin{array}{c}\text { Communication } \\
\text { service }\end{array}$} & $n \begin{array}{l}\text { Dormitor } \\
\text { y service }\end{array}$ \\
\hline $\begin{array}{c}\text { Record and } \\
\text { documentati } \\
\text { on } \\
\text { management }\end{array}$ & \multicolumn{2}{|c|}{$\begin{array}{c}\text { Definitions of work } \\
\text { flow and } \\
\text { documentation }\end{array}$} & \multicolumn{3}{|c|}{$\begin{array}{l}\text { Work flow } \\
\text { implementation }\end{array}$} & & $\begin{array}{l}\text { Work fl } \\
\text { supervis }\end{array}$ & $\begin{array}{l}\text { low } \\
\text { sion }\end{array}$ & \multicolumn{3}{|c|}{$\begin{array}{l}\text { Record and } \\
\text { documentation } \\
\text { management }\end{array}$} & \multicolumn{2}{|c|}{$\begin{array}{l}\text { Information } \\
\text { exploitation }\end{array}$} \\
\hline $\begin{array}{c}\text { Human } \\
\text { resource } \\
\text { management }\end{array}$ & \multicolumn{2}{|c|}{$\begin{array}{l}\text { Department and } \\
\text { position system } \\
\text { management }\end{array}$} & & cruitment & \multicolumn{2}{|c|}{$\begin{array}{c}\text { Administrat } \\
\text { ive and } \\
\text { personnel } \\
\text { manageme } \\
\text { nt }\end{array}$} & $\begin{array}{r}\text { Time } \\
\text { manage }\end{array}$ & ement & \multicolumn{2}{|c|}{$\begin{array}{l}\text { Human } \\
\text { resource } \\
\text { development } \\
\text { and training }\end{array}$} & \multicolumn{2}{|c|}{$\begin{array}{c}\text { Benefit and } \\
\text { pension } \\
\text { management }\end{array}$} & $\begin{array}{c}\text { Salary } \\
\text { manage } \\
\text { ment }\end{array}$ \\
\hline $\begin{array}{l}\text { Materials and } \\
\text { services }\end{array}$ & \multicolumn{3}{|c|}{$\begin{array}{l}\text { Material procurement } \\
\text { management }\end{array}$} & \multicolumn{2}{|c|}{\begin{tabular}{c|c} 
Stock \\
management
\end{tabular}} & \multicolumn{4}{|c|}{$\begin{array}{l}\text { Material and equipment } \\
\text { management }\end{array}$} & \multicolumn{2}{|c|}{$\begin{array}{l}\text { Liquidation } \\
\text { service }\end{array}$} & \multicolumn{2}{|c|}{$\begin{array}{l}\text { Material and } \\
\text { equipment } \\
\text { arrangement }\end{array}$} \\
\hline $\begin{array}{l}\text { Service } \\
\text { trading } \\
\text { support }\end{array}$ & Cash at & $d$ treasur & ry $\mathrm{n}$ & lagement & $\begin{array}{r}\text { Pro } \\
\text { man }\end{array}$ & $\begin{array}{l}\text { perty } \\
\text { ageme } \\
\text { nt }\end{array}$ & & $\begin{array}{l}\text { Real } \\
\text { manag }\end{array}$ & $\begin{array}{l}\text { estate } \\
\text { jement }\end{array}$ & & Busine & ess trip ma & anagement \\
\hline
\end{tabular}

Figure 1. Model of the ERP of the SAP, Application to some Universities in the World

\subsection{Technical Infrastructure IT - the Result of the Synchronization of Infrastructure, the Specialized Database and Application Common}

In the general information system, The web portal architecture (Portal) is illustrated to build a logical manner and ensuring adequate basic elements for operation (infrastructure), data for exploitation. They used with corresponding business processes, be concretized through integrated applications on database systems and specialized mechanisms and policies to maintain continuous systems, safety and security data (Figure 2). 


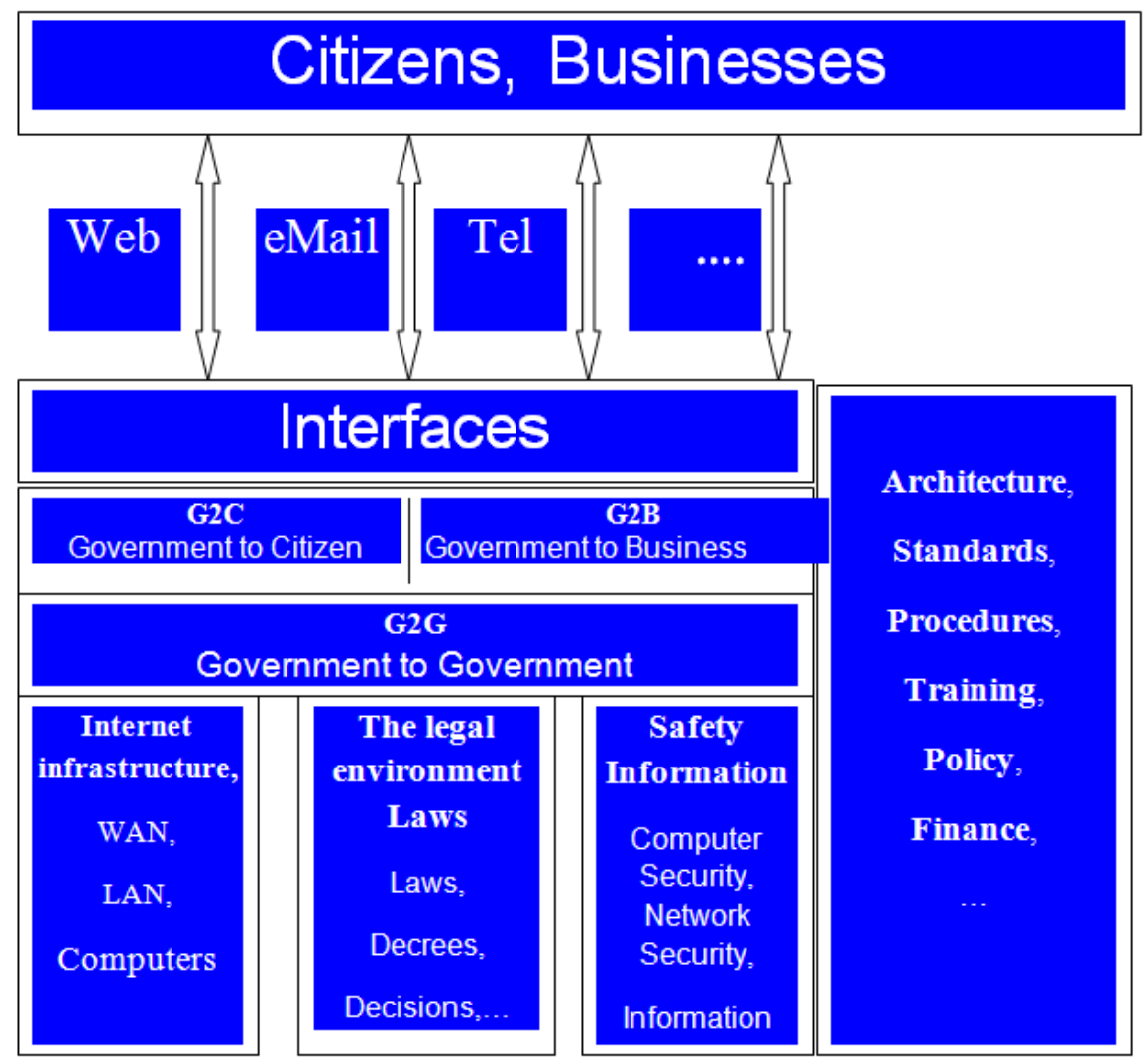

Figure 2. Portal Layered Architecture

In Figure 2, describe the system portal (is integrated all the web-based applications) as a result of the synchronization of infrastructure, database, application and exploitation methods.

\subsection{Technical Infrastructure IT}

Grade of infrastructure including hardware devices ensures system operation as intranet information, transmission and signal acquisition lighting control, security, energy. Included: Server database, transmission infrastructure, the Internet connection speed, device security information systems, system monitoring equipment and control of electrical equipment in the event, set with near field communication (RFID, NFC). It allows the use of magnetic cards to manage, and use the services of schools and other devices connected to the network and communication of the information.

The nucleus of the whole technical infrastructure is of the data center (Data Center), is the place for where is sharing, updating and distributing of data commons, data integration from application system modules, is data warehouse services searching for individuals and organizations inside and outside the school.

\subsection{Database System Focused}

"Infrastructure common and centralized database" - is the architectural framework of the process throughout the design, build database systems, the common application module in schools. It makes sure system integrity, continuity and data mining capabilities effectively. From the experience of the process of building e-government in Vietnam, until now the construction of the national database system major is the key to perform the synchronization information infrastructure in the nationwide. Databases inhabitants are typical, this which is the basic data and the most important to the other databases, all 
systems can link applications, integrating, sharing, unified, synchronized on set of attributes has calculated basis.

Therefore, the survival of an information system depends significantly on the information infrastructure, system of specialized databases are allocate resources to operating systems and support decision making.

In technology, software platform and service platform, the software that runs the server, allowing the school building and deploying applications and services and the management of functional modules, training, and data storage, digital libraries, .... The application platform may be the open platform (OpenSource) as OpenSource ERP for schools, Java, MySQL, Linux ..., or trade backgrounds such as Microsoft .NET.

\subsection{Sharing Application}

The modules of operational in management model in universities \& colleges we have built under the following forms: Application Web, mobile, desktop. Web applications are built integrated mainly through web portal allows school users convenient through Internet. The functional modules are built diversity and abundance to serve the work of the departments of the school and was built with the goal of maximizing the automation process information with the help of a computer. In order to build an IT system synchronized and efficient operation, it requests designing and building information standards and information flows and scientific standards for information systems of the (Dictionary system).

This is the top layer of communication systems including applications, services, functional modules, user interfaces, electronic document systems,.... These applications are standardized and can form a unified ERP system created in schools. Application layer have a very important role, because it is integrated, as the output of all management information through data mining capabilities of the university in all management activities, training, scientific research, communications faculty and students, some library systems, security monitoring systems.

\subsection{Synchronize and SSO (Single Sign-On)}

Synchronize and specialized databases systems, applications sharing in the school was incorporated according to the Single sign-on solution (login one-time) providing the flexibility in business operations, unified in handling data. To be able to use IT systems as the right to $\log$ in classrooms, laboratories, printers, borrow books at the library, information search, ... staff, lecturers, students use their accounts in the form of username and password, or identity card (student card or staff card using wireless communication technology) to log into the system SSO mechanism, login one-time with a account using system provides functions and services. Account login is also E- mail account used to exchange contact information, used in examinations and school notices. 


\section{Digital Opportunity}

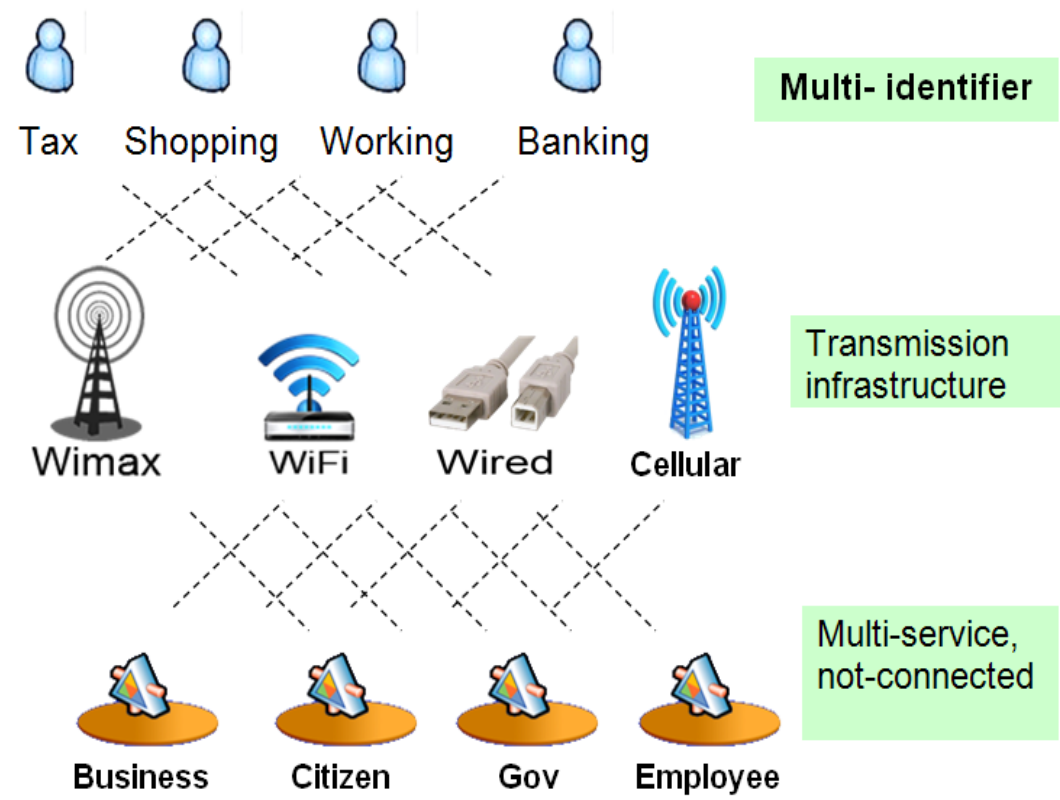

\section{Figure 3. The Challenge of Digital Opportunities (Intel Digital Cities Core Services Framework)}

For data synchronization, data structures and efficient operation, these modules have the standard, common in unified process of system and system modules; Data standards for specialized databases, data interchange standards between units outside the system, business process operations, process data sharing, process data output,... All data standards and processes are open and ongoing improvements to correct with national regulations and interact with standards, procedures and advanced technology in the world.

\section{Uniform integrity}

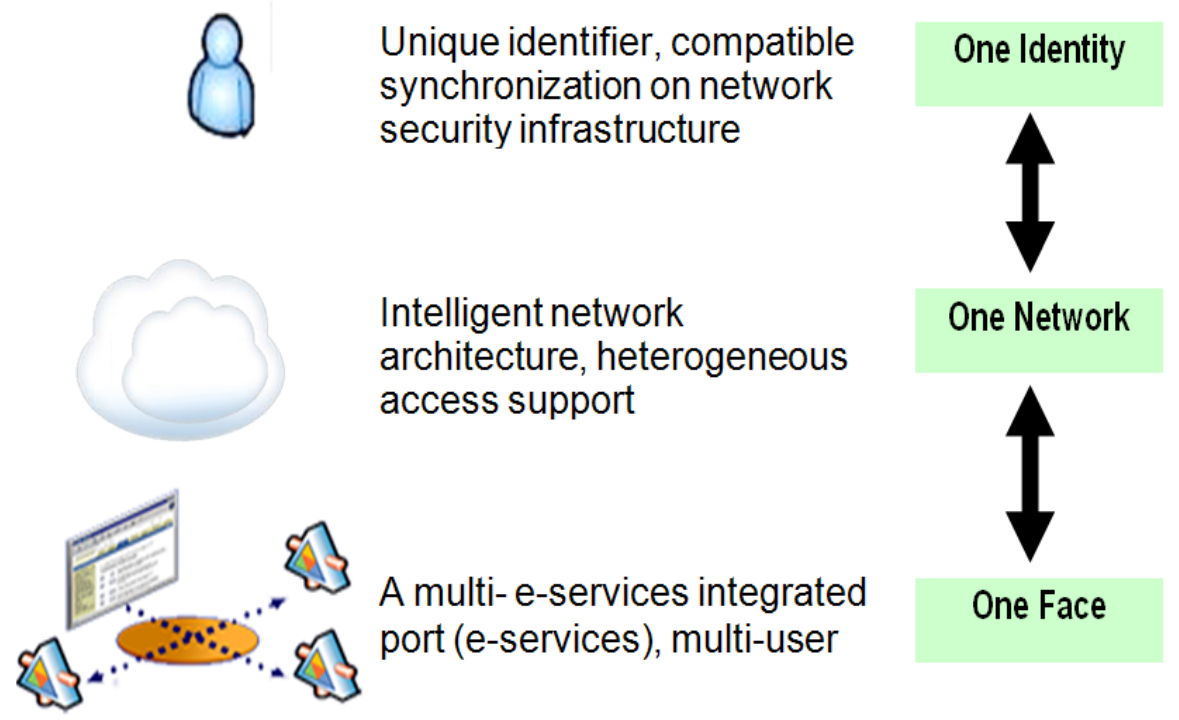

Figure 4. Integration is the Solution to Conflict Handling for Information Systems (Intel Digital Cities Core Services Framework) 


\subsection{Effectiveness in Capacity Management and Administration: Determinants of Quality of University Education}

Efficiency and saving of IT applications is always a words of a lot of people, many leaders and management. However, to turn the "know, say forever" was a reality is a way need determination, perseverance and patience in directing the implementation. With the changes in work habits from desk to keyboard, from paper documents to electronic documents, from notices in the table to the email alert, was the "breakthrough" on changes recognized knowledge workers (can say that time changes in 10 years).

\section{Conclusion}

One of the important stages of the process of managing is the supervise and inspection system. If the monitoring, testing is done regularly, methodically, then this information will bring very good response for the improvement of management capacity and portability of process management.

Application of IT governance that promotes transparency, "transparent" management of processes, create efficient in directing, executive and operational environments are highly interactive. This is both the basis and driving force for promoting innovation process, improve the quality of teaching for the disciplines, the field of training and create the dynamics for faculty staff.

During training oriented information and communications technology of the area, Vietnam have invested strategic from technical infrastructure, equipment, manpower and qualified information infrastructure are the decisive factors to create the foundation for sustainable development in the developing stages of Vietnam in each stage of development of the school. The synchronization from executive management capacity, the adjustment cycle of infrastructure and the dynamism and creativity of the human team will make up the new developments, corresponding to the position of the country.

\section{References}

[1] A. Abugabah and L. Sanzogni, "ERP system in Higher Education: A literature review and implications", International Journal of Human and Social Sciences, vol. 5, no. 6, (2010).

[2] D. F.Rico, "ERP in Higher Education", http://davidfrico.com/rico04f.pdf. (2004).

[3] H. Ho Cam, H. Le Huy and T. Nguyen Chi, "An application of Information Technology in the university Management", Publisher of National University, Hanoi, Vietnam, (2013).

[4] T. Vu Ngoc, ERP in University (CMC Soft), (2012).

[5] T. Nguyen Manh and H. Huynh Thi Hong, "An application of ERP to the credit - based training management", Journal of Science and Technology, Danang University, Vietnam, (2010).

\section{Author}

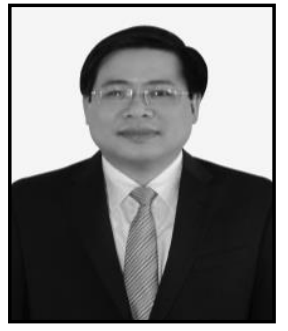

Hung Hoang Bao, graduated from Hue University of Education, Vietnam in 1993, majoring in Mathematics. In 2002, Master Degree in IT, Hanoi Polytechnic University. In 2007, PhD thesis at the Institute of IT, Vietnam Academy of Science and Technology. Currently working at the Korea-Vietnam Friendship IT College under the management of the Ministry of Information and Communications. His research interests include object database, GIS, cloud computing, e-GOV. 